\title{
Effects of minerals on feed degradation and protein synthesis by rumen micro-organisms in a dual effluent fermenter
}

\author{
Laurent-Philippe Broudiscou ${ }^{\mathrm{a} *}$, Yves Papon ${ }^{\mathrm{a}}$, Anne F. Broudiscou ${ }^{\mathrm{b}}$ \\ ${ }^{a}$ Département de l'élevage et nutrition des animaux, Inra, Paris, France \\ ${ }^{b}$ LPRAI, 31190 Miremont, France
}

(Received 10 July 1998; accepted 27 January 1999)

\begin{abstract}
In dual outflow continuous fermenters on a 75:25 hay/barley diet, feed degradation and protein synthesis by mixed rumen microbes were tested in relation to the concentrations of $\mathrm{HPO}_{4}{ }^{2-}, \mathrm{HCO}_{3}{ }^{-}$and $\mathrm{Cl}^{-}$and $\mathrm{Na}^{+} / \mathrm{K}^{+}$ratio in artificial saliva, by applying a 16-run Franquart design, and by fitting second-order polynomial models. The $\mathrm{HPO}_{4}{ }^{2-}, \mathrm{HCO}_{3}{ }^{-}, \mathrm{Cl}^{-}$concentrations and $\mathrm{Na}^{+} / \mathrm{K}^{+}$ ratio ranged from 0.1 to $4 \mathrm{~g} \cdot \mathrm{L}^{-1}$, from 0.5 to $7 \mathrm{~g} \cdot \mathrm{L}^{-1}$, from 0.1 to $0.5 \mathrm{~g} \cdot \mathrm{L}^{-1}$ and from 0.5 to $15 \mathrm{~g} \cdot \mathrm{g}-1$, respectively. Buffer salts, particularly $\mathrm{HPO}_{4}{ }^{2-}$, were the major factors while $\mathrm{Cl}^{-}$concentration had negligible effects on microbial metabolism. Maximal neutral detergent fibre, acid detergent fibre and organic matter degradabilities occurred at intermediate values of $\mathrm{HPO}_{4}{ }^{2-}$ and $\mathrm{HCO}_{3}$ - concentrations. The outflow of microbial protein and the efficiency of microbial protein synthesis, which varied from 26.2 to $37.1 \mathrm{~g} \cdot \mathrm{N} \cdot \mathrm{kg}^{-1}$ of organic matter truly degraded, reached minima at the centre of the experimental domain. (C) Inra/Elsevier, Paris.
\end{abstract}

mineral / rumen / micro-organism / proteosynthesis

Résumé - Effet des minéraux sur la dégradation des aliments et la synthèse de protéines par les microbes du rumen en fermenteur à double effluent. Les effets des concentrations de $\mathrm{HPO}_{4}{ }^{2-}$, $\mathrm{HCO}_{3}^{-}, \mathrm{Cl}^{-}$et du rapport $\mathrm{Na}^{+} / \mathrm{K}^{+}$, dans la salive artificielle, sur la dégradation des aliments et la synthèse de protéines par les microbes du rumen ont été quantifiés dans des fermenteurs à effluent double recevant une ration $75 \%$ foin $/ 25 \%$ orge, en appliquant une matrice de Franquart et à l'aide de modèles polynomiaux du second degré. Les concentrations de $\mathrm{HPO}_{4}{ }^{2-}, \mathrm{HCO}_{3}{ }^{-}, \mathrm{Cl}^{-}$et le rapport $\mathrm{Na}^{+} / \mathrm{K}^{+}$ont respectivement varié de 0,1 à $4 \mathrm{~g} \cdot \mathrm{L}^{-1}$, de 0,5 à $7 \mathrm{~g} \cdot \mathrm{L}^{-1}$, de 0,1 à $0,5 \mathrm{~g} \cdot \mathrm{L}^{-1}$ et de 0,5 à $15 \mathrm{~g} \cdot \mathrm{g}^{-1}$. Les facteurs les plus influents ont été les minéraux tampons, particulièrement $\mathrm{HPO}_{4}{ }^{2-}$. Les dégradabilités du neutral detergent fibre, de l'acid detergent fibre et de la matière organique ont été maximales pour des valeurs centrales des concentrations de $\mathrm{HPO}_{4}{ }^{2-}$ et $\mathrm{HCO}_{3}{ }^{-}$. Le flux de protéines microbiennes

\footnotetext{
* Correspondence and reprints

Laboratoire de nutrition et alimentation, I.N.A.P.G., 16, rue Claude-Bernard, 75231 Paris cedex 05, France

E-mail: broudis@clermont.inra.fr
} 
et l'efficacité de leur synthèse, de 26,2 à $37,1 \mathrm{~g} \mathrm{~N} \cdot \mathrm{kg}^{-1}$ de matière organique réellement dégradée, ont été minimaux au centre du domaine expérimental. () Inra/Elsevier, Paris.

\section{minéral / rumen / micro-organisme / synthèse de protéines}

\section{INTRODUCTION}

The role of minerals in regulating the metabolism of rumen micro-organisms is recognised $[20,39]$ and their effects have been investigated in diverse experimental situations. In husbandry conditions, the supplementation of ruminants with buffer salts, to counteract the detrimental effects of highconcentrate diets [41], or the changes induced by sodium and potassium on rumen functions [35] have been evaluated. In order to formulate adequate culture media [11, 13], microbiologists have studied the effect of specific ions on bacterial growth in pure culture. Continuous culture systems offer opportunities to gain information on the direct response of mixed rumen microbes to a change in mineral supply. In animals, a similar treatment would affect the host digestive physiology (e.g. the rumen content's dilution rate and absorption rates of metabolites) and would also have indirect consequences on rumen microbes. Moreover, dual effluent continuous fermenters, well suited to the design of the experiments, allow data collection on a large set of factors within a single trial at reasonable expense.

In a previous paper [9], we described the influence of salivary salts on fermentation variates, in a continuous culture of mixed rumen microbes maintained on a standard diet. In the present report, we are considering the relationships between the same mineral compounds and the utilisation of feeds by microbes to produce biomass, in particular proteins. Some preliminary results are in the process of publication in abstract form [10].

\section{MATERIALS AND METHODS}

\subsection{Experimental strategy}

The major inorganic components of natural and artificial salivas are potassium or sodium salts of bicarbonate, of hydrogen and dihydrogen phosphate, and of chloride. In vitro, the $\mathrm{pH}$ may be adjusted by addition of $\mathrm{KOH}$ or $\mathrm{NaOH}$. The main characteristics of any saliva can, thus, be defined by four variables: 1) the amount of phosphates, expressed as hydrogen phosphate equivalent $\left.\left(\mathrm{HPO}_{4}{ }^{2-}\right) ; 2\right)$ the amount of carbonates expressed as bicarbonate equivalent $\left.\left(\mathrm{HCO}_{3}^{-}\right) ; 3\right)$ the amount of chloride $\left(\mathrm{Cl}^{-}\right)$; and 4) the ratio of sodium to potassium amounts $\left(\mathrm{Na}^{+} / \mathrm{K}^{+}\right)$. These variables were used as experimental factors in our study, and we aimed at determining their quantitative effect on rumen microbe metabolism. The quantities of $\mathrm{HPO}_{4}{ }^{2-}$, $\mathrm{HCO}_{3}{ }^{-}$and $\mathrm{Cl}^{-}$in our trial (table $I$ ) reproduced physiological variations around the average values reported by Clarke [14] and Durand and Kawashima [20]. A distinctive feature of the $\mathrm{Na}^{+} / \mathrm{K}^{+}$factor was the location of the values of greatest interest at the periphery of the experimental domain rather than at its centre, since the $\mathrm{Na}^{+} / \mathrm{K}^{+}$ratios in most salivas were close to either 14 or $2[1,4,24,27,38,45,51]$. We thus dimensioned the variation interval of this factor to include both sets of values.

Published data have clearly demonstrated linear or quadratic responses of bacterial growth $[2,12,16,29,30,43,47]$ or enzymatic activity $[2$, $26]$ to physiological changes in mineral supply, in accordance with the law of ecological tolerance formulated by V.E. Shelford in 1913. Therefore, we modelled the relationships between experimental factors and microbial metabolism parameters using second-order polynomial equations. Response surface methodology, extensively reviewed in the statistics literature $[5,15]$, provided an efficient experimental strategy to determine the relationships between the four independent variables and the responses relative to microbial metabolism. We explored the spherical 
Table I. Limits of the experimental domain.

\begin{tabular}{|c|c|c|c|c|}
\hline \multirow[t]{2}{*}{ Independent variables } & \multicolumn{2}{|c|}{ Symbols } & \multicolumn{2}{|c|}{ Levels } \\
\hline & Coded & Natural & Coded & Natural \\
\hline Amount of hydrogen phosphate & HPo & $\mathrm{HPO}_{4}{ }^{2-}\left(g \cdot \mathrm{L}^{-1}\right)$ & $\begin{array}{l}-1 \\
+1\end{array}$ & $\begin{array}{r}0.1 \\
4\end{array}$ \\
\hline Amount of bicarbonate & $\mathrm{HCo}$ & $\mathrm{HCO}_{3}^{-}\left(\mathrm{g} \cdot \mathrm{L}^{-1}\right)$ & $\begin{array}{l}-1 \\
+1\end{array}$ & $\begin{array}{r}0.5 \\
7\end{array}$ \\
\hline Amount of chloride & $\mathrm{Cl}$ & $\mathrm{Cl}^{-}\left(\mathrm{g} \cdot \mathrm{L}^{-1}\right)$ & $\begin{array}{l}-1 \\
+1\end{array}$ & $\begin{array}{l}0.1 \\
0.5\end{array}$ \\
\hline Ratio sodium/potassium & $\mathrm{NaK}$ & $\mathrm{Na}^{+} / \mathrm{K}^{+}\left(\mathrm{g} \cdot \mathrm{g}^{-1}\right)$ & $\begin{array}{l}-1 \\
+1\end{array}$ & $\begin{array}{r}0.5 \\
15\end{array}$ \\
\hline
\end{tabular}

domain comprised within the values given in table 1 , using an experimental design published by Franquart [23]. This design was found using simulated annealing with D-optimality for criterion. Rather than selecting a central composite design for this trial, we employed a Franquart design, which also led to a valid estimate of the response surface model, though with a much smaller number of experiments. We have compared the main characteristics of both designs in table II, as summarised by Peissik [44], since the Franquart design has not yet been published in the agronomic or statistical literature. Maximal inflation factors are equally satisfactory (below 4) and the Franquart design is close to orthogonality. Using this design leads to an adequate prediction of dependent variables (or responses), with a maximal variance function dMax of 1 . The Franquart design is almost rotatable, as shown by the Khuri index of above $98 \%$ [36]. Our experimental worksheet is shown in table III. All runs, except \#16, are evenly distributed at the edge of the four-dimensional experimental domain. Run \#16, at the centre, was applied three times to give an estimation of experimental error. The 18 runs were randomly assigned to six independent fermenters, identically assembled, which were operated for three 7-day contiguous experimental periods. The randomisation was justified by a preliminary trial, where the fermenters were run for two 11-day experimental periods with no statistically significant differences between periods or between fermenters for most measurements (Broudiscou, unpublished data).
Table II. Characteristics of Franquart and central composite designs.

Franquart Central composite

\begin{tabular}{lcc}
\hline Number of runs & 16 & 25 \\
Factor levels & $7 ; 7 ; 7 ; 7$ & $5 ; 5 ; 5 ; 5$ \\
Trace $\left(X^{\prime} X\right)^{-1}$ & 18.34 & 15.22 \\
$F_{i}$ & 1 & 1 \\
$F_{i i}$ & 1.62 & 1 \\
$F_{i j}$ & 1.01 & 1 \\
Khuri index $(\%)$ & 99.6 & 89.2 \\
G-efficiency $(\%)$ & 93.75 & 33.74 \\
\hline
\end{tabular}

$X$ : design matrix; $F_{i j} F_{i r} F_{i j}:$ maximal inflation factors for the terms $X_{i}, X_{i}^{2}$ and $X_{i j}$

\subsection{Incubation procedure}

The rumen contents used as inoculum were withdrawn after a 24 -h fasting period from two wethers, fed twice daily $1000 \mathrm{~g} \cdot \mathrm{d}^{-1}$ chopped hay and $200 \mathrm{~g} \cdot \mathrm{d}^{-1}$ ground and pelleted barley. The inoculation protocol was described in Broudiscou et al. [8]. Each fermenter, maintained at $39^{\circ} \mathrm{C}$, was continuously infused with one of the 16 tested salivas. All the salivas were supplemented with $0.4 \mathrm{~g} \cdot \mathrm{L}^{-1} \mathrm{HCl}-$ cysteine as reducing agent. The fermentation broths were separately supplemented with $31.7 \mathrm{mg} \cdot \mathrm{d}^{-1} \mathrm{CaCl}_{2}, 47.5 \mathrm{mg} \cdot \mathrm{d}^{-1}$ $\mathrm{MgCl}_{2}$ and $0.755 \mathrm{~g} \cdot \mathrm{d}^{-1}\left(\mathrm{NH}_{4}\right)_{2} \mathrm{SO}_{4}$. Ten grams of a pelleted diet made of $750 \mathrm{~g} \cdot \mathrm{kg}^{-1}$ orchardgrass hay (dry matter content of $92.1 \%$ ) and $250 \mathrm{~g} \cdot \mathrm{kg}^{-1}$ ground barley (dry matter content of 
Table III. Experimental worksheet.

\begin{tabular}{lcccc}
\hline & \multicolumn{4}{c}{ Experimental factors } \\
\cline { 2 - 3 } Run \# & $\mathrm{HPO}_{4}{ }^{2-}\left(\mathrm{g} \cdot \mathrm{L}^{-1}\right)$ & $\mathrm{HCO}_{3}^{-}\left(\mathrm{g} \cdot \mathrm{L}^{-1}\right)$ & $\mathrm{Cl}^{-}\left(\mathrm{g} \cdot \mathrm{L}^{-1}\right)$ & $\mathrm{Na}^{+} / \mathrm{K}^{+}\left(\mathrm{g} \cdot \mathrm{g}^{-1}\right)$ \\
\hline 1 & 1.3597 & 1.7610 & 0.4224 & 10.3165 \\
2 & 1.3597 & 5.7390 & 0.1776 & 10.3165 \\
3 & 2.7403 & 1.7610 & 0.1776 & 10.3165 \\
4 & 2.7403 & 5.7390 & 0.4224 & 10.3165 \\
5 & 0.5875 & 2.3428 & 0.2134 & 9.5625 \\
6 & 0.5875 & 5.1573 & 0.3866 & 9.5625 \\
7 & 3.5125 & 2.3428 & 0.3866 & 9.5625 \\
8 & 3.5125 & 5.1573 & 0.2134 & 9.5625 \\
9 & 0.6714 & 3.7500 & 0.3000 & 2.6243 \\
10 & 3.4287 & 3.7500 & 0.3000 & 2.6243 \\
11 & 2.0500 & 0.9355 & 0.3000 & 4.1250 \\
12 & 2.0500 & 6.5645 & 0.3000 & 4.1250 \\
13 & 2.0500 & 3.7500 & 0.1268 & 4.1250 \\
14 & 2.0500 & 3.7500 & 0.4732 & 4.1250 \\
15 & 2.0500 & 3.7500 & 0.3000 & 15.0000 \\
16 & 2.0500 & 3.7500 & 0.3000 & 7.7500 \\
\hline
\end{tabular}

* See table I for symbols.

$91.1 \%$ ) was supplied to the fermenters at $10 \mathrm{~h} 00$ and $20 \mathrm{~g}$ at $18 \mathrm{~h} 00$. The composition of feeds is given in table $I V$. The dilution rates of particle and liquid phases were set at $0.03 \mathrm{~h}^{-1}$ and $0.06 \mathrm{~h}^{-1}$, respectively. The procedures followed to control the two turnover rates, and for the daily collection of deplaced and filtered effluents, were identical to Broudiscou et al. [8].

\subsection{Analytical methods}

After a 5-day adaptation term, the deplaced and filtered effluents collected on days 6 and 7 were pooled and kept at $-20{ }^{\circ} \mathrm{C}$ until sub-sampled for dry matter (DM), volatile fatty acids (VFA) and ammonia nitrogen $\left(\mathrm{NH}_{3}{ }^{-} \mathrm{N}\right)$ determination. The samples for VFA and $\mathrm{NH}_{3}-\mathrm{N}$ analysis were mixed with 0.1 volume of $\mathrm{H}_{3} \mathrm{PO}_{4} 8.2 \%$ $(\mathrm{w} / \mathrm{w})$ and stored at $-20^{\circ} \mathrm{C}$ until analysis. The remaining effluents were freeze-dried. At the end of the incubation period, the fermentation broth was strained and the feed residue in the liquid phase was separated by centrifugation at $1500 \mathrm{~g}$ for $10 \mathrm{~min}$. The supernatant was centrifuged at $27000 \mathrm{~g}$ for $30 \mathrm{~min}$ to isolate the liquid-associated bacterial (LAB) fraction. The bacterial pellet was resuspended into $90 \mathrm{~g} \cdot \mathrm{L}^{-1} \mathrm{NaCl}$,
Table IV. Composition of feeds

\begin{tabular}{lcc}
\hline$\left(\mathrm{g} \cdot \mathrm{kg}^{-1} \mathrm{DM}\right)$ & Hay & Barley \\
\hline Organic matter & 913 & 924 \\
Crude protein $(\mathrm{N} \times 6.25)$ & 148 & 129 \\
Neutral detergent fibre & 634 & 157 \\
Acid detergent fibre & 342 & 60
\end{tabular}

centrifuged at $27000 \mathrm{~g}$ for $30 \mathrm{~min}$ and freezedried. Feeds and freeze-dried effluents were ground prior to analysis using a Culatti grinder with a $0.8-\mathrm{mm}$ screen. Feed, effluent and bacterial samples were analysed for DM, organic matter (OM) [7], neutral detergent fibre (NDF), and acid detergent fibre (ADF) [50]. Total nitrogen was measured by the micro-Kjeldahl technique. $\mathrm{NH}_{3}-\mathrm{N}$ was determined as described by Davies and Taylor [18]. VFA were determined as described by Jouany [31]. Effluent and bacterial samples were analysed for nucleobases according to Lassalas et al. [32] using a diode-array detector (Beckman Instruments, Fullerton). Phosphorus in feeds was determined by AFNOR standard method NF V 18-106. 


\subsection{Calculations}

Spectral analysis of HPLC separation showed an impurity occurring within the peak of cytosine for most bacterial and effluent samples. We thus discarded this pyrimidine base from the pool of nucleobases used as a microbial marker. The outflows of microbial $\mathrm{OM}$ and of microbial $\mathrm{N}$ (MN) were determined from nucleobases by two calculation methods. In the first one, the microbial reference pool was the commonly used LAB. In the second one, the microbial reference was also calculated from the LAB chemical composition but a fraction of nucleobase outflow was attributed to solid-associated bacteria (SAB) by applying the following hypotheses: the LAB represents $20 \%$ of the bacterial DM outflow, the ash and the nucleobase contents of DM are both $55 \%$ lower in SAB than in $\mathrm{LAB}$ and the $\mathrm{SAB}$ nitrogen contents is $1 \mathrm{~g} \mathrm{~N} / 100 \mathrm{~g}$ DM lower than in LAB. The outflows of microbial OM and N resulting from the correction due to $S A B$ biomass were used to calculate the true $\mathrm{OM}$ and $\mathrm{N}$ degradabilities, and the efficiency of microbial protein synthesis (EMPS). The true OM degradability $\left(\mathrm{td}_{\mathrm{OM}}\right)$ was determined by equation (1):

$$
\begin{aligned}
& \operatorname{td}_{O M}(\%)=100 \times\left(\mathrm{g} \cdot \mathrm{d}^{-1}\right. \text { microbial } \\
& \mathrm{OM}+\mathrm{g} \cdot \mathrm{d}^{-1} \text { fermented } \mathrm{OM} \text { ) } \\
& \mathrm{g} \cdot \mathrm{d}^{-1} \text { dietary OM }
\end{aligned}
$$

The daily amount of OM fermented (OMF) was estimated from outflows of individual VFA by equation (2), derived from the relation given by Demeyer and Van Nevel [19] to calculate the amounts of fermented hexose:

$$
\begin{gathered}
\text { OMF }\left(\mathrm{g} \cdot \mathrm{d}^{-1}\right)=162 \times[(\mathrm{C} 2+\mathrm{C} 3) / 2+ \\
\mathrm{IC} 4+\mathrm{C} 4+\mathrm{IC} 5+\mathrm{C} 5]
\end{gathered}
$$

where $\mathrm{C} 2, \mathrm{C} 3, \mathrm{IC} 4, \mathrm{C} 4, \mathrm{IC} 5$ and $\mathrm{C} 5$ were the daily outflows $\left(\mathrm{mol} \cdot \mathrm{d}^{-1}\right)$ of acetate, propionate, isobutyrate, butyrate, isovalerate and valerate, respectively.

The amount of nucleic acids in LAB was estimated from nucleobase analysis by considering that the molar fractions of cytosine, adenine and guanine included into DNA equalled the ratio [thymine]/[thymine + uracil].

\subsection{Statistical analyses}

The results were submitted to stepwise regression by an SAS procedure [46]. The following second-order polynomial model was fitted to data:

$$
Y=b_{0}+\sum_{i=1}^{4} b_{i} \cdot X_{i}+\sum_{i=1}^{4} b_{i i} \cdot X_{i}^{2}+\sum_{i=1}^{3} \sum_{j>j} b_{i j} X_{i} \cdot X_{j}
$$

where $X_{i}$ were the four coded variables presented in table $I$, and $b_{0}, b_{i}, b_{i i}$ and $b_{i j}$ the 15 coefficients to be estimated. The coded variables $X_{i}$, used in multiple linear regression, varied from -1 to +1 . They were related to the experimental factors $N_{i}$, also called natural variables, by the equation:

$$
X_{i}=2 *\left(N_{i}-N_{i}^{0}\right) / \Delta N_{i}
$$

in which $N_{i}^{0}$ is the value at the centre of the domain, and $\Delta N_{i}$ is the interval of variation of $N_{i}$. For instance, $N_{i}^{0}$ and $\Delta N_{i}$ equalled 2.05 and $3.9 \mathrm{~g} \cdot \mathrm{L}^{-1}$, respectively, for variable $\mathrm{HPO}_{4}{ }^{2-}$. The F statistic significance level for deleting or adding a variable was set to 0.15 . We assessed the goodness or the lack of fit of the models by visual analysis of the response residuals. The results were also submitted to response surface polynomial regression, with no selection among model terms [46].

\section{RESULTS}

All the regression analyses were performed on 17 runs, as one repetition of experiment \#16 was stopped owing to technical failure. The numerical results of stepwise regressions are given in the tables. In the model-fitting procedure, we did not apply the marginality principle - the term for $X_{i}^{2}$ or $X_{i} X_{j}$ could remain even if the term for $X_{i}$ or $X_{j}$ had been excluded - because none of our variables was discrete [3]. The addition or the deletion of a term in the model was only determined by the level of significance of the F statistic. The coefficients for excluded terms were set at zero in the tables. The absence of a term in a table meant that it was deleted in all the reported models. The degrees of freedom for the error term, being easily determined from the number of terms finally included in the model for each response variable, were not inserted in the tables. The outputs of response surface analysis are presented in the figures, owing to the large number of coefficients in the corresponding models. For all response variables, the model coefficients estimated by stepwise regression 
and by full-model regression were very close and led to similar conclusions.

The model coefficients for apparent and true degradabilities of feed constituents are presented in table $V$. NDF degradability $\left(\mathrm{d}_{\mathrm{NDF}}\right)$ ranged from 32.9 to $71.3 \%$, and averaged $49.3 \%$. The model provided a satisfactory fit to data, characterised mainly by quadratic effects of all four factors, the major one being $\mathrm{HPO}_{4}{ }^{2-}$. The maximal degradation was thus attained in the central part of the experimental domain. Figure 1 shows the contour plot of $\mathrm{d}_{\mathrm{NDF}}$ for $\mathrm{HPO}_{4}{ }^{2-}$ and $\mathrm{HCO}_{3}{ }^{-}$concentrations, at $\mathrm{Cl}^{-}$concentration and $\mathrm{Na}^{+} / \mathrm{K}^{+}$values of $0.3 \mathrm{~g} \cdot \mathrm{L}^{-1}$ and $7.75 \mathrm{~g} \cdot \mathrm{g}^{-1}$, which are the co-ordinates of the central point in our experimental domain. When using the figures, one must remember that the precision of the prediction is substantially degraded outside of the spherical domain we have explored. The ADF degradability $\left(\mathrm{d}_{\mathrm{ADF}}\right)$ was poorly explained by the model, and was only influenced in a quadratic way by $\mathrm{HPO}_{4}{ }^{2-}$ and $\mathrm{Na}^{+} / \mathrm{K}^{+}$. The apparent $\mathrm{OM}$ degradability $\left(\mathrm{ad}_{\mathrm{OM}}\right)$ and the true $\mathrm{OM}$ degradability $\left(\mathrm{td}_{\mathrm{OM}}\right)$ varied from 19.1 to $37.7 \%$ and from 52.6 to $64.0 \%$ (with an average value of $60.1 \%$ ), respectively. The degradation of $\mathrm{OM}$ demonstrated a conjugated action of $\mathrm{HCO}_{3}^{-}$, in a quadratic way, and of $\mathrm{Cl}^{-}$. Figure 2 presents the contour plot of $\mathrm{td}_{\mathrm{OM}}$ for $\mathrm{HCO}_{3}^{-}$and $\mathrm{Cl}^{-}$concentrations, at constant $\mathrm{HPO}_{4}{ }^{2-}$ and $\mathrm{Na}^{+} / \mathrm{K}^{+}$ values of $2.05 \mathrm{~g} \cdot \mathrm{L}^{-1}$ and $7.75 \mathrm{~g} \cdot \mathrm{g}^{-1}$.

The amount of fermented OM, with an adjusted $R^{2}$ of 0.36 , was minimal with high or low values of $\mathrm{HCO}_{3}{ }^{-}$and $\mathrm{HPO}_{4}{ }^{2-}$. The apparent and true $\mathrm{N}$ degradabilities, ranging from 3.1 to $13.0 \%$ and from 74.2 to $85.9 \%$, respectively, were more closely

Table V. Stepwise regression applied to the degradabilities (\%) of NDF $\left(\mathrm{d}_{\mathrm{NDF}}\right)$ and ADF $\left(\mathrm{d}_{\mathrm{ADF}}\right)$, apparent $\left(\mathrm{ad}_{\mathrm{OM}}\right)$ and true $\left(\mathrm{td}_{\mathrm{OM}}\right)$ organic matter degradabilities, fermented organic matter (FOM) $\left(\mathrm{g} \cdot \mathrm{d}^{-1}\right)$, and apparent $\left(\mathrm{ad}_{\mathrm{N}}\right)$ and true $\left(\mathrm{td}_{\mathrm{N}}\right)$ nitrogen degradabilities.

\begin{tabular}{lccccccc}
\hline & $\mathrm{d}_{\mathrm{NDF}}$ & $\mathrm{d}_{\mathrm{ADF}}$ & $\mathrm{ad}_{\mathrm{OM}}$ & $\mathrm{td}_{\mathrm{OM}}$ & $\mathrm{FOM}$ & $\mathrm{ad}_{\mathrm{N}}$ & $\mathrm{td}_{\mathrm{N}}$ \\
\hline R-square & 0.83 & 0.43 & 0.57 & 0.65 & 0.52 & 0.63 & 0.97 \\
Adjusted $\mathrm{R}^{2}$ & 0.70 & 0.35 & 0.43 & 0.53 & 0.36 & 0.50 & 0.95 \\
$\mathrm{RSD}$ & 5.31 & 7.96 & 3.89 & 1.90 & 0.646 & 1.91 & 0.849 \\
\hline Terms & Coefficients & & & & & & \\
\hline Intercept & 67.2 & 57.6 & 31.9 & 61.4 & 10.51 & 10.5 & 76.5 \\
$\mathrm{HPo}^{\mathrm{a}}$ & -4.8 & 0 & $-4.6^{*}$ & 0 & 0 & 0 & $1.3^{*}$ \\
$\mathrm{HCo}^{2}$ & 0 & 0 & 0 & 0 & 0 & 0 & $4.4^{* *}$ \\
$\mathrm{Cl}$ & $7.1^{*}$ & 0 & 0 & $2.2^{*}$ & 0.56 & $3.2^{* *}$ & 0 \\
$\mathrm{HPo}{ }^{2}$ & $-31.5^{* *}$ & $-24.6^{*}$ & $-11.5^{*}$ & 0 & -1.15 & -3.4 & $6.2^{* *}$ \\
$\mathrm{HCo}{ }^{2}$ & $-16.6^{*}$ & 0 & 0 & $-6.4^{* *}$ & $-1.60^{*}$ & $-5.8^{*}$ & 0 \\
$\mathrm{Cl}$ & -12.5 & 0 & 0 & 0 & 0 & 0 & $6.8^{* *}$ \\
$\mathrm{NaK}{ }^{2}$ & $-22.2^{* *}$ & -15.1 & -6.8 & 0 & 0 & -3.8 & 0 \\
$\mathrm{HPo} \times \mathrm{Cl}$ & 0 & 0 & 0 & 0 & 0 & 0 & $-2.6^{*}$ \\
$\mathrm{HPo} \times \mathrm{NaK}$ & 0 & 0 & 0 & 0 & 0 & 0 & $6.5^{* *}$ \\
$\mathrm{HCo} \times \mathrm{Cl}$ & 13.3 & 0 & 0 & 4.2 & 1.58 & 0 & 0 \\
$\mathrm{HCo} \times \mathrm{NaK}$ & 0 & 0 & 0 & 0 & 0 & 0 & $4.6^{* *}$ \\
$\mathrm{Cl} \times \mathrm{NaK}$ & 0 & 0 & -7.6 & 5.0 & 0 & 0 & $6.3^{* *}$ \\
\hline
\end{tabular}

a See table $I$ for symbols. 0 : coefficient estimate non-significantly different from null $(P>0.15)$. Levels of significance for the null hypothesis: $* P<0.05 ; * * P<0.01$. 
Figure 1. Contour plot of NDF degradability (\%) for hydrogen ophos phate $\left(\mathrm{HPO}_{4}{ }^{2-}\right)$ and bicarbonate $\left(\mathrm{HCO}_{3}^{-}\right)$concentrations, with chloride concentration and sodium/potassium ratio values set at $0.3 \mathrm{~g} \cdot \mathrm{L}^{-1}$ and $7.75 \mathrm{~g} \cdot \mathrm{g}^{-1}$.

Figure 2. Contour plot of true OM degradability (\%) for bicarbonate $\left(\mathrm{HCO}_{3}^{-}\right)$ and chloride $\left(\mathrm{Cl}^{-}\right)$concentrations, with hydrogenophosphate and sodium/ potassium ratio values set at $2.05 \mathrm{~g} \cdot \mathrm{L}^{-1}$ and $7.75 \mathrm{~g} \cdot \mathrm{g}^{-1}$.
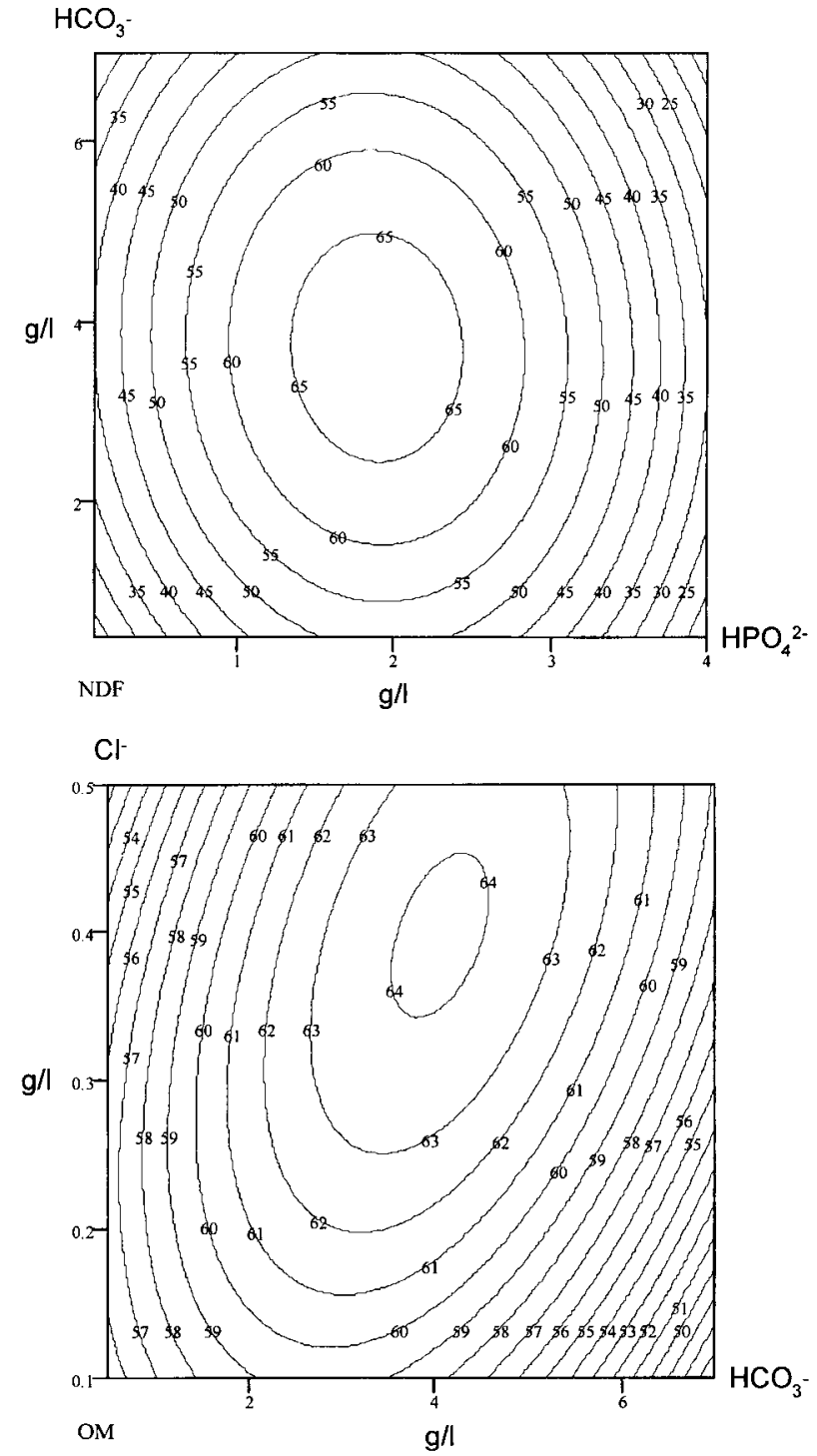

related to experimental factors. The apparent $\mathrm{N}$ digestibility was linearly increased by a $\mathrm{Cl}^{-}$concentration increase and, in a quadratic way, first by $\mathrm{HCO}_{3}^{-}$, then by $\mathrm{HPO}_{4}{ }^{2-}$ concentrations and the $\mathrm{Na}^{+} / \mathrm{K}^{+}$ratio. The effects of experimental factors on true $\mathrm{N}$ digestibility were more complex, with a linear increase with respect to $\mathrm{HCO}_{3}{ }^{-}$concentration and a favourable influence of low and high values of $\mathrm{HPO}_{4}{ }^{2-}$ and $\mathrm{Cl}^{-}$. The $\mathrm{Na}^{+} / \mathrm{K}^{+}$ratio was involved in a number of positive interactions, while both its linear and quadratic coefficients were clearly negligible.

For NAN and microbial N outflows, regression analysis led to acceptable fits (table VI). The microbial $\mathrm{N}$ outflows varied from 0.304 to $0.390 \mathrm{~g} \cdot \mathrm{d}^{-1}$ when the 
Table VI. Stepwise regression applied to the daily outflows of non-ammonia nitrogen (NAN), microbial nitrogen determined from $\mathrm{LAB}$ only $(\mathrm{MN})$, microbial nitrogen corrected for $\mathrm{SAB}(\mathrm{CMN})$ and to the efficiency of microbial protein synthesis (EMPS) $\left(\mathrm{g} \cdot \mathrm{N} \cdot \mathrm{kg}^{-1}\right.$ OMTD).

\begin{tabular}{|c|c|c|c|c|}
\hline & \multicolumn{3}{|c|}{ Outflows $\left(g \cdot d^{-1}\right)$} & \multirow[t]{2}{*}{ EMPS } \\
\hline & NAN & $\mathrm{MN}$ & $\mathrm{CMN}$ & \\
\hline R-square & 0.63 & 0.58 & 0.55 & 0.89 \\
\hline Adjusted $\mathrm{R}^{2}$ & 0.50 & 0.44 & 0.40 & 0.77 \\
\hline RSD & 0.0129 & 0.0145 & 0.0219 & 1.29 \\
\hline Term & \multicolumn{3}{|l|}{ Coefficient } & \\
\hline Intercept & 0.608 & 0.336 & 0.476 & 28.3 \\
\hline $\mathrm{HPo}^{\mathrm{a}}$ & 0 & 0.015 & 0.019 & 1.3 \\
\hline $\mathrm{HCo}$ & 0 & $0.019 *$ & $0.027^{*}$ & $2.1 *$ \\
\hline $\mathrm{Cl}$ & $-0.022 * *$ & -0.014 & -0.022 & $-2.7 * *$ \\
\hline $\mathrm{HPo}^{2}$ & 0.023 & 0.034 & 0.048 & $5.6^{* *}$ \\
\hline $\mathrm{HCo}^{2}$ & $0.039 *$ & 0 & 0 & $5.9 * *$ \\
\hline $\mathrm{Cl}^{2}$ & 0 & 0 & 0 & 3.1 \\
\hline $\mathrm{NaK}^{2}$ & 0.026 & 0 & 0 & 0 \\
\hline $\mathrm{HCo} \times \mathrm{Cl}$ & 0 & 0 & 0 & $-3.7^{*}$ \\
\hline $\mathrm{HCo} \times \mathrm{NaK}$ & 0 & 0 & 0 & 3.2 \\
\hline
\end{tabular}

a See table I for symbols. 0: coefficient estimate non-significantly different from null $(P>0.15)$. Levels of significance for the null hypothesis: ${ }^{*} P<0.05 ; * * P<0.01$.

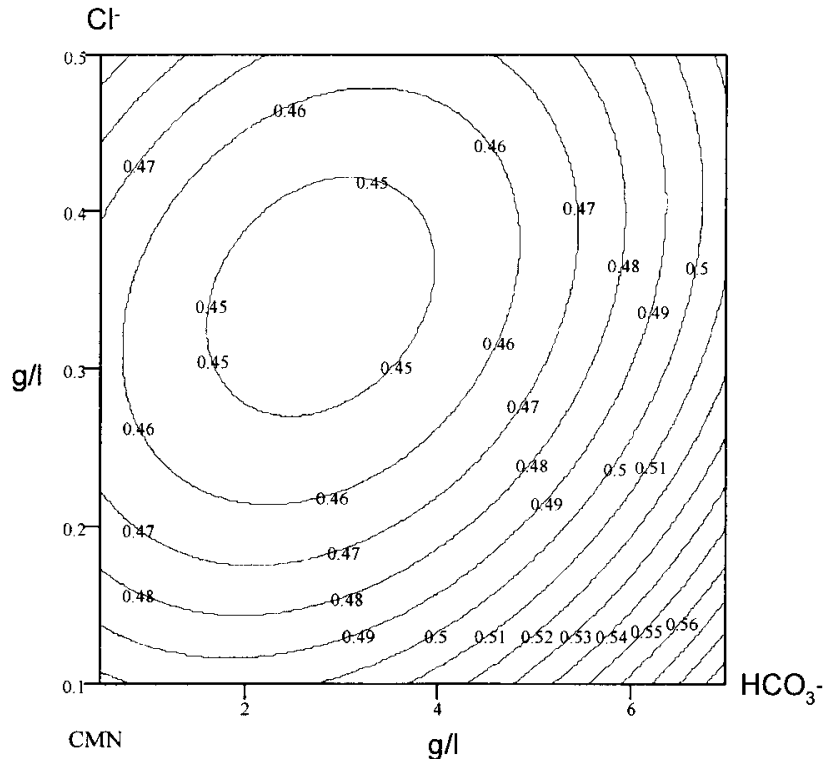

Figure 3. Contour plot of microbial nitrogen $(\mathrm{CMN})$ outflow $\left(\mathrm{g} \cdot \mathrm{d}^{-1}\right)$ for bicarbonate $\left(\mathrm{HCO}_{3}^{-}\right)$and chloride $\left(\mathrm{Cl}^{-}\right)$concentrations, with hydrogenophosphate and sodium/potassium ratio values set at $2.05 \mathrm{~g} \cdot \mathrm{L}^{-1}$ and $7.75 \mathrm{~g} \cdot \mathrm{g}^{-1}$. 
Figure 4. Contour plot of microbial nitrogen (CMN) outflow $\left(g \cdot d^{-1}\right)$ for hydrogenophosphate $\left(\mathrm{HPO}_{4}^{2-}\right)$ and bicarbonate $\left(\mathrm{HCO}_{3}^{-}\right)$concentrations, with chloride concentration and sodium/ potassium ratio values set at $0.3 \mathrm{~g} \cdot \mathrm{L}^{-1}$ and $7.75 \mathrm{~g} \cdot \mathrm{g}^{-1}$.

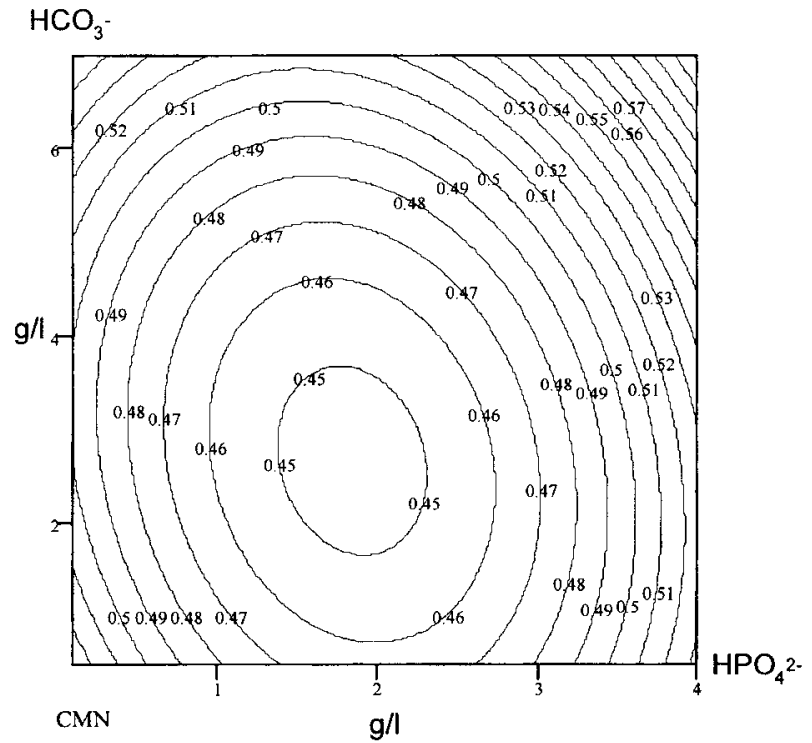

microbial reference was $\mathrm{LAB}$, and from 0.429 to $0.555 \mathrm{~g} \cdot \mathrm{d}^{-1}$ when the presence of $\mathrm{SAB}$ was also considered. The estimation of EMPS ranged from 26.2 to $37.1 \mathrm{~g} \mathrm{~N} \cdot \mathrm{kg}^{-1}$ OMTD. Whatever the calculation method, the models for the amount of microbial protein synthesised showed a curvilinear positive effect of $\mathrm{HPO}_{4}{ }^{2-}$, and opposed linear influences of $\mathrm{HCO}_{3}{ }^{-}$and $\mathrm{Cl}^{-}$(figures 3 and 4). The EMPS estimation (table VI) was satisfactorily modelled, with strong curvilinear positive influences of $\mathrm{HPO}_{4}{ }^{2-}$ and $\mathrm{HCO}_{3}{ }^{-}$concentrations (figure 5) and a negative effect of $\mathrm{Cl}^{-}$interacting with $\mathrm{HCO}_{3}^{-}$. Maxima occurred for high values of $\mathrm{HPO}_{4}{ }^{2-}$ and $\mathrm{HCO}_{3}^{-}$and low values of $\mathrm{Cl}^{-}$. The composition of $\mathrm{LAB}$ is presented in table VII. All the responses except the $\mathrm{N}$ contents were satisfactorily modelled. Bacterial organic matter ranged from 82.2 to $90.3 \mathrm{~g} / 100 \mathrm{~g}$ DM. It showed a linear negative effect of $\mathrm{HPO}_{4}{ }^{2-}$ and $\mathrm{HCO}_{3}{ }^{-}$, and was also lowered by low or high values of $\mathrm{Na}^{+} / \mathrm{K}^{+}$. The nucleic acid contents, the $\mathrm{N}$ contents and the ratio [nucleic acids]/[nitrogen] were comprised between 61.7 and $75.3 \mathrm{mg} \cdot \mathrm{g}^{-1}$ OM, 90.5 and $109.5 \mathrm{mg} \cdot \mathrm{g}^{-1} \mathrm{OM}, 0.634$ and $0.734 \mathrm{~g} \cdot \mathrm{g}^{-1}$, respectively. With nucleic acids, the most active factor was clearly the $\mathrm{Na}^{+} / \mathrm{K}^{+}$ ratio, acting both in a curvilinear negative way and through negative interactions with the other factors. The nucleic acid content was the lowest for high $\mathrm{Na}^{+} / \mathrm{K}^{+}$values. The $\mathrm{N}$ content was merely influenced by $\mathrm{Na}^{+} / \mathrm{K}^{+}$ and $\mathrm{Cl}^{-}$. The regression analysis for the ratio [nucleic acids]/[nitrogen] mainly demonstrated opposite curvilinear influences of $\mathrm{HCO}_{3}{ }^{-}$and $\mathrm{Cl}^{-}$.

\section{DISCUSSION}

The present paper, which deals with the effects of mineral compounds on feed degradation and microbial growth in a continuous culture system, completes former reports about the action of these minerals on microbial fermentation in the same experiment ([9]; Broudiscou et al., in press). Since all data have been analysed, our experimental scheme can now be thoroughly evaluated as a strategy whose benefits make it superior to a number of others. As $\mathrm{Cl}^{-}$effects appeared to be for the most part negligible, would it have been wiser to screen all factors 


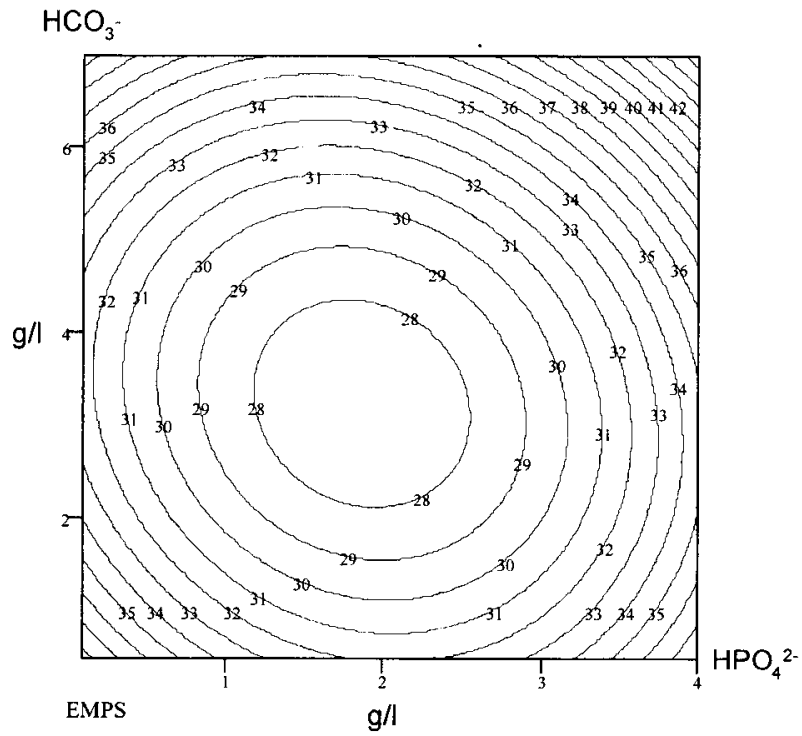

Figure 5. Contour plot of efficiency of microbial protein synthesis (EMPS: $\mathrm{g}$ $\mathrm{N} \cdot \mathrm{kg}^{-1}$ OMTD) for hydrogenophosphate $\left(\mathrm{HPO}_{4}{ }^{2-}\right)$ and bicarbonate $\left(\mathrm{HCO}_{3}^{-}\right)$ concentrations, with chloride concentration and sodium/potassium ratio values set at of $0.3 \mathrm{~g} \cdot \mathrm{L}^{-1}$ and $7.75 \mathrm{~g} \cdot \mathrm{g}^{-1}$.

Table VII. Stepwise regression applied to the chemical composition of liquid associated bacteria: OM, nucleic acids (NA), nitrogen (N) and ratio [nucleic acids]/[nitrogen].

\begin{tabular}{lcccc}
\hline & $\begin{array}{c}\text { OM } \\
(\% \mathrm{DM})\end{array}$ & $\begin{array}{c}\text { Nucleic acids } \\
\left(\mathrm{mg} \cdot \mathrm{g}^{-1} \mathrm{OM}\right)\end{array}$ & $\begin{array}{c}\text { Nitrogen } \\
\left(\mathrm{mg} \cdot \mathrm{g}^{-1} \mathrm{OM}\right)\end{array}$ & $\begin{array}{c}\mathrm{NAN} \\
\left(\mathrm{g} \cdot \mathrm{g}^{-1}\right)\end{array}$ \\
\hline R-square & 0.93 & 0.95 & 0.42 & 0.83 \\
Adjusted $\mathrm{R}^{2}$ & 0.89 & 0.90 & 0.34 & 0.69 \\
RSD & 0.93 & 1.00 & 4.07 & 0.0174 \\
\hline Term & Coefficient & & & \\
\hline Intercept & 86.4 & 68.7 & 103.4 & 0.686 \\
$\mathrm{HPo}$ & $-3.5^{* *}$ & 0 & 0 & 0 \\
$\mathrm{HCo}$ & $-4.2^{* *}$ & $-1.4^{*}$ & 0 & $-0.032^{* *}$ \\
$\mathrm{Cl}$ & 0 & 0 & $-4.5^{*}$ & $0.026^{*}$ \\
$\mathrm{NaK}$ & 0 & $-3.3^{* *}$ & 0 & -0.017 \\
$\mathrm{HCo}{ }^{2}$ & 0 & 0 & 0 & -0.039 \\
$\mathrm{Cl}$ & 0 & $7.0^{* *}$ & 0 & 0.033 \\
$\mathrm{NaK}$ & & $-4.0^{* *}$ & $-9.6^{*}$ & 0 \\
$\mathrm{HPo} \times \mathrm{HCo}$ & $-2.7^{*}$ & $4.4^{*}$ & 0 & 0 \\
$\mathrm{HPo} \times \mathrm{Cl}$ & 0 & 0 & 0 & 0.037 \\
$\mathrm{HPo} \times \mathrm{NaK}$ & $-3.2^{*}$ & $-4.0^{*}$ & 0 & $-0.065^{*}$ \\
$\mathrm{HCo} \times \mathrm{NaK}$ & 0 & $-3.6^{*}$ & 0 & 0 \\
$\mathrm{Cl} \times \mathrm{NaK}$ & 0 & -2.2 & 0 & 0 \\
\hline
\end{tabular}

a See table I for symbols. 0: non-significantly different from null $(P>0.15)$. Levels of significance for the null hypothesis: $* P<0.05 ; * * P<0.01$. 
and include only the most important ones in the polynomial model? With such an approach, one first implements a factorial $3 \times 2^{3}$ design, containing 12 experiments [25], to obtain all the main effects and twofactor interactions. One then adds at least seven (preferably ten) experiments to the initial matrix to generate a central composite design and to model the actions of $\mathrm{HPO}_{4}{ }^{2-}, \mathrm{HCO}_{3}{ }^{-}$and $\mathrm{Na}^{+} / \mathrm{K}^{+}$, which have proved to be important factors. In this sequential strategy, the total number of experiments was at least 19, instead of 16 in the Franquart matrix, to obtain similar information on the processes under study. Our experimental strategy was justified by the relatively small number of factors under consideration.

The degradabilities and the EMPS reported in the present paper were all in accordance with the values commonly measured in animals. The difference between $\mathrm{td}_{\mathrm{OM}}$ and $\mathrm{d}_{\mathrm{NDF}}$, in particular, accounted for the extensive degradation of barley starch, almost absent from effluent samples. The method used to calculate $\mathrm{td}_{\mathrm{OM}}$ in our experiment was justified by the imbalance between OM inflows and outflows observed in all our experimental runs. The most probable explanation was the presence of significant amounts of VFA in freeze-dried effluent samples. In ruminants, most of the VFA produced is absorbed across the forestomach walls, without reaching the duodenal fistula [22]. In our fermenters, all the fermentation end-products were collected. An analysis of water-extracts of dried effluent samples clearly showed that VFA were only partially eliminated through freeze-drying. These VFA are inadvertently taken for undegraded dietary OM (or DM) if one applies a method adapted from in vivo experiments to calculate $\mathrm{td}_{\mathrm{OM}}-$ or true DM digestibility, as described by Crawford et al. [17]. In our experiment, the equation used to estimate the OMF took into account the fermentation of pentoses released through pectin and hemicellulose degradation [34], and the much less significant fer- mentation of carbon chains resulting from amino acid deamination. The mineral concentrations in our experimental domain were comprised within physiological limits [20]. The ions linked to each experimental factor have well-defined metabolic roles. Phosphates contribute to the buffering capacity of the medium, and phosphorus is a constituent of nucleic acids, phospholipids and coenzymes. Bicarbonates are efficient buffers at a $\mathrm{pH}$ near 6.5, and methanogens use carbon dioxide as an electron acceptor. Chloride salts merely change osmotic pressure. Potassium is a major ion in microbial cells, especially as a cofactor for such enzymes as phosphohexokinases. A number of halophilic rumen bacterial species require sodium [20].

As for fermentation variates (Broudiscou et al., in press), buffers $\left(\mathrm{HCO}_{3}{ }^{-}, \mathrm{HPO}_{4}{ }^{2-}\right)$ were the most active factors on substrate hydrolysis and microbial synthesis. However, while fermentation and OM degradation were mainly influenced by $\mathrm{HCO}_{3}^{-}$, $\mathrm{HPO}_{4}{ }^{2-}$ appeared to be a major factor in the degradation of cell wall constituents and proteins. It has been clearly established [37] that a deficiency in phosphorus inhibits cellulolysis. In our experiment, phosphorus was supplied in a readily available form and apparently met microbial requirements expressed in terms of fermentable energy in all runs, with at least $20 \mathrm{mg} \cdot \mathrm{g}^{-1} \mathrm{OMF}$ [21]. Nevertheless, the explored domain was probably wide enough to induce, in a number of experimental runs, phosphorus concentrations low enough to be slightly harmful. The effects of high values have been poorly documented and their cause was unclear. As expected, NDF degradability followed the same pattern as acetate production (Broudiscou et al., in press). Bicarbonate probably influenced cell wall degradation by changes in $\mathrm{pH}$. Stewart [48] reported a similar relationship between $\mathrm{pH}$ and cotton degradation by mixed rumen microbes. The nature of cations influenced fibre degradation as well, in accordance with the findings of Hubbert et al. [28] on cellu- 
lose digestion in batch incubations of mixed suspensions of rumen micro-organisms. St Omer and Roberts [49], however, found no effect of potassium on crude fibre apparent digestibility in experiments with heifers. The model fit to true nitrogen degradability presented a specific feature - significant positive interactions between the $\mathrm{Na}^{+} / \mathrm{K}^{+}$ ratio and other factors - which might be merely interpreted as a positive effect of small amounts of potassium on protein hydrolysis. Mackie and Therion [39] have stressed the greater sensitivity of microbes to higher concentrations of potassium than sodium. In our experiments, the concentrations of $\mathrm{Na}^{+}$and $\mathrm{K}^{+}$in the saliva varied from 2.1 to $4.4 \mathrm{~g} \cdot \mathrm{L}^{-1}$ and from 0.22 to $1.3 \mathrm{~g} \cdot \mathrm{L}^{-1}$, respectively. One should note that the nature of cations also affected the branched chain VFA production rate (Broudiscou et al., in press). Both observations suggest specific metabolic requirements for a number of proteolytic bacterial strains. In general, our data clearly demonstrated that most of the variables related to feed degradation were kept constant in the central part of our experimental domain.

The microbial matter flowing out of the fermenters was mostly of bacterial origin. Taking into account the protozoa bio-volumes, chemical composition and outflow rate reviewed by Williams and Coleman [52], one can estimate from protozoa counts [9] that these micro-organisms accounted for $2-5 \%$ of the daily microbial nitrogen outflow. The correction for the portion of bacterial matter outflow of SAB origin was based on the bibliography relating to $\mathrm{SAB}$ chemical composition $[6,33,40,42,54]$ and to $\mathrm{SAB} / \mathrm{LAB}$ ratio in the ruminal or duodenal bacterial matter $[33,53,54]$ on a mixed diet. This calculation method led to more sensible values for $\mathrm{MN}$ outflow, $\mathrm{td}_{\mathrm{OM}}$ and EMPS, but did not modify the conclusions on the influence of experimental factors, which were only based on observations of LAB. In our experiment, the daily outflow of microbial $\mathrm{N}$ was kept relatively constant in a large central area of the experi- mental domain but tended to vary inversely to OM degradation as a function of experimental factors. This trend led to a minimisation of the EMPS at intermediate values of mineral inputs. Nevertheless, one must note that EMPS, although well modelled, varied within a rather narrow range. Within our experimental conditions, the practical consequences of mineral supply on microbial protein synthesis were hardly noticeable. The comparison of the effect of $\mathrm{HPO}_{4}{ }^{2-}$ on microbial protein synthesis with its effect on fibre degradation, in particular, was consistent with the findings of Komisarczuk et al. [37] on the different phosphorus requirements for cellulose digestion and for protein synthesis. The chemical composition of bacterial matter was markedly altered by minerals. The ash content of LAB, although partly related to the mineral content of wash solution used in the isolation procedure [40], varied directly as buffer salt concentrations in the culture medium. Moreover, the nature and amount of cations strongly influenced the nucleic acid content in bacterial organic matter and to a lesser degree, the $\mathrm{N}$ content, which might be interpreted both as a change in the specific composition of bacterial populations and as an effect on bacterial growth rates.

In our experimental conditions, the influences of minerals on feed degradation and protein synthesis were reduced in scale. Fibre degradability was the only variable which was simultaneously well modelled and exhibited extended variations throughout the experimental domain. Moreover, most of the parameters investigated were kept relatively constant within a large central area of the domain. In conclusion, the artificial saliva formulated in a former paper [9] and containing intermediate amounts of buffer salts should warrant an acceptable stability for in vitro studies of microbial processes in the rumen. 


\section{ACKNOWLEDGEMENTS}

The authors would like to thank Dr S. Komisarzuk-Bony for analysis of phosphorus in feeds, $\mathrm{Mr}$ R. Bergeault for fibre determination, Mrs B. Lassalas for other laboratory analyses, and L. L'Hotelier for taking care of experimental animals.

\section{REFERENCES}

[1] Aafjes J.H., Nijhof J.K., A simple artificial rumen giving good production of volatile fatty acids, Br. Vet. J. 123 (1967) 436-445.

[2] Atlas R.M., Bartha R., Microbial Ecology, Fundamentals and Applications, Benjamin/Cummings Publishing Company, Redwood City, 1993.

[3] Benoist D., Tourbier Y., Germain-Tourbier S., Plans d'expériences : Construction et Analyse, Lavoisier, Paris, 1994.

[4] Bowie W.C., In vitro studies of rumen microorganisms, using a continuous-flow system, Am. J. Vet. Res. 23 (1962) 858-868.

[5] Box G.E.P., Hunter W.G., Hunter J.S., Statistics for Experimenters: An Introduction to Design, Data Analysis and Model Building, John Wiley, New York 1978.

[6] Broudiscou L.-P., Introduction d'un hydrolysat d'huile de soja ou d'une huile de lin dans la ration de moutons : influence sur la digestion des aliments, thèse, Institut national agronomique Paris-Grignon, 1988.

[7] Broudiscou L.-P., Pochet S., Poncet C., Effect of linseed oil supplementation on feed degradation and microbial synthesis in the rumen of ciliate-free and refaunated sheep, Anim. Feed Sci. Technol. 49 (1994) 189-202.

[8] Broudiscou L.-P., Papon Y., Fabre M., Broudiscou A.F., Maintenance of rumen protozoa populations in a dual outflow continuous fermenter, J. Sci. Food Agric. 75 (1997) 273-280.

[9] Broudiscou L.-P., Papon Y., Broudiscou A.F., Effect of minerals on methane production and protozoa numbers in continuous culture of rumen micro-organisms. Reprod. Nutr. Dev. suppl. 1 (1997) 70-71.

[10] Broudiscou, L.-P., Papon, Y., Broudiscou, A.F., Effet de la supplémentation minérale sur le métabolisme azoté des micro-organismes du rumen, étude en fermenteur à effluent double, in: Proceedings of the 5 th Rencontres Recherches Ruminants, 2-3 December 1998, Inra Editions, Paris, 1998

[11] Bryant M.P., Robinson I.M., Chu H., Observations on the nutrition of Bacteroides succinogenes - a ruminal cellulolytic bacterium, J. Dairy Sci. 42 (1959) 1831-1847.
[12] Caldwell D.R., Keeney M., Barton J.S., Kelley J.F., Sodium and other inorganic growth require ments of Bacteroides amylophilus, J. Bacteriol 114 (1973) 782-789.

[13] Caldwell D.R., Arcand C., Inorganic and metalorganic growth requirements of the genus Bacteroides, J. Bacteriol. 120 (1974) 322-333.

[14] Clarke R.T.J., Methods for studying gut microbes, in: Clarke R.T.J., Bauchop T. (Eds.) Microbial Ecology of the Gut, Academic Press, London, 1977, pp. 1-33.

[15] Cochran W.G., Cox G.M., Experimental Designs, John Wiley, New York, 1957.

[16] Cote R.J., Gherna R.L., Nutrition and media, in: Gerhardt P., Murray R.G.E., Wood W.A., Krieg N.R. (Eds.), Methods for General and Molecular Bacteriology, ASM, Washington, 1994, pp. 155-177

[17] Crawford R.J., Hoover W.H., Knowlton P.H. Effects of solids and liquid flows on fermentation in continuous cultures. I. Dry matter and fiber digestion, VFA production and protozoa numbers, J. Anim. Sci. 51 (1980) 975-985.

[18] Davies A.W., Taylor, K., Application of the autoanalyser in a river authority laboratory, in Symposium Technicon, Technicon, Tarrytown 1965, pp. 294-300.

[19] Demeyer D.I., Van Nevel C.J., Methanogenesis, an integrated part of carbohydrate fermentation and its control, in: McDonald I.W., Warner A.C.I. (Eds.), Digestion and Metabolism in the Ruminant, University of New England Publishing, Armidale, 1975, pp. 366-382.

[20] Durand M., Kawashima R., Influence of minerals in rumen microbial digestion, in: Ruckebush Y., Thivend P. (Eds.), Digestive Physiology and Metabolism in Ruminants, MTP Press, Lancaster, 1980, pp. 375-408.

[21] Durand M., Komisarczuk S., Influence of major minerals on rumen microbiota, J. Nutr. 118 (1988) 249-260.

[22] France J., Siddons R.C., Volatile fatty acid production, in: Forbes J.M., France J. (Eds.), Quantitative Aspects of Ruminant Digestion and Metabolism, C.A.B. International, Wallinford, 1993, pp. 107-121.

[23] Franquart P., Optimisations multicritères et méthodologie de la recherche expérimentale, thèse, université d'Aix-Marseille, 1992.

[24] Gray F.V., Weller R.A., Pilgrim A.F., Jones, G.B., A stringent test for the artificial rumen, Austr. J. Agric. Res. 13 (1962) 343-349.

[25] Haaland P.D., Experimental Design in Biotechnology, Marcel Dekker, New York, 1989.

[26] Halpern Y.S., Barash H., Dover S., Druck K., Sodium and potassium requirements for active transport of glutamate by Escherichia coli $\mathrm{K}$ 12, J. Bacteriol. 114 (1973) 53-58. 
[27] Hino T., Sugiyama M., Okumura K., Maintenance of protozoa and methanogens, and fiber digestion in rumen-simulating continuous culture, J. Gen. Appl. Microbiol. 39 ( 1993) 35-45.

[28] Hubbert F., Cheng E., Burroughs W., The influence of potassium, sodium, rubidium, lithium and cesium on in vitro cellulose digestion by rumen micro-organisms with observations upon sodium and potassium influences in lamb fattening rations, J. Anim. Sci. 17 (1958) 576-585.

[29] Iijima T., Diesterhaft M.D., Freese E., Sodium effect of growth on aspartate and genetic analysis of a Bacillus subtilis mutant with high aspartase activity, J. Bacteriol 129 (1977) 1440-1447.

[30] Ingram L.O., Thurston E.L., Potassium requirements for cell division in Anacystis nidulans, J. Bacteriol. 125 (1976) 369-371.

[31] Jouany J.-P., Volatile fatty acid and alcohol determination in digestive contents, silage juices, bacterial cultures and anaerobic fermentor contents, Sci. Aliments 2 (1982) 131-144.

132] Lassalas B., Jouany J.P., Broudiscou, L., Dosage des bases puriques et pyrimidiques par chromatographie liquide à haute performance, Ann. Zootech. 42 (1993) 170-171.

[33] Legay-Carmier F., Bauchart D., Distribution of bacteria in the rumen contents of dairy cows given a diet supplemented with soya-bean oil, Br. J. Nutr. 61 (1989) 725-740.

[34] Lin K.W., Patterson J.A., Ladisch M.R., Anaerobic fermentations: microbes from ruminants, Enz. Microb. Technol. 7 (1985) 98-107.

[35] Khorasani G.R., Armstrong D.G., Effect of sodium and potassium on overall digestibility of a semi-purified diet and microbial protein production in the rumen of sheep, Livestock Prod. Sci. 24 (1990) 347-357.

[36] Khuri A.I., A measure of rotatability for response-surface designs, Technometrics 30 (1988) 95-104.

[37] Komisarczuk S., Merry R.J., McAllan A.B., Effects of different levels of phosphorus on rumen microbial fermentation and synthesis determined using a continuous culture system, Br. J. Nutr. 57 (1987) 279-290.

[38] McDougall E.I., Studies on ruminant nutrition. I. The composition and output of sheep's saliva, Biochem. J. 43 (1948) 99-109.

[39] Mackie R.I., Therion J.J., Influence of mineral interactions on growth efficiency of rumen bacteria, in: Gilchrist F.M.C., Mackie R.I. (Eds.), Herbivore Nutrition, Craighall: Science Press, London, 1984, pp. 455-477.

[40] Martin C., Williams A.G., Michalet-Doreau B., Isolation and characteristics of the protozoal and bacterial fractions from bovine ruminal contents, J. Anim. Sci. 72 (1994) 2962-2968.
[41] Mees D.C, Merchen N.R., Mitchel C.J., Effects of sodium bicarbonate on nitrogen balance, bacterial protein synthesis and sites of nutrient digestion in sheep, J. Anim. Sci. 61 (1985) 985-994.

[42] Merry R.J., McAllan A.B., A comparison of the chemical composition of mixed bacteria harvested from the liquid and solid fractions of rumen digesta, Br. J. Nutr. 50 (1983) 701-709.

[43] O'Brien R.W., Stern J.R., Requirements for sodium in the anaerobic growth of Aerobacter aerogenes on citrate, J. Bacteriol. 98 (1969) 388-393.

[44] Peissik A.. Méthodologie de la recherche expérimentale : propriétés et caractéristiques des matrices d'expériences pour les modèles polynomiaux du second degré, thèse, université d'Aix-Marseille, 1995.

[45] Rufener W.H., Nelson W.O., Wolin M.J., Maintenance of the rumen microbial population in continuous culture, Appl. Microbiol. 11 (1963) 196-201.

[46] SAS/S'TAT ${ }^{(19}$, User's Guide, Release 6.04, SAS Institute Inc, Cary, 1990.

[47] Sistrom W.R., A requirement for sodium in the growth of Rhodopseudomonas spheroides, J. Gen. Microbiol, 22 (1960) 778-785.

[48] Stewart C.S., Factors affecting the cellulolytic activity of rumen contents, Appl. Environ. Microbiol. 33 (1977) 497-502.

[49] St Omer V.V.E., Roberts W.K., Some effects of dietary potassium upon digestibility, serum electrolytes and utilization of potassium, sodium, nitrogen and water in heifers, Can. J. Anim. Sci. 47 (1967) 39-46.

[50] Van Soest P.J., Wine R.H., Use of detergents in the analysis of fibrous feeds. Determination of plant cell-wall constituents, J. A. O. A. C. 50 (1967) 50-55.

[51] Weller R.A., Pilgrim A.F., Passage of protozoa and volatile fatty acids from the rumen of the sheep and from a continuous in vitro fermentation system, Br. J. Nutr. 32 (1974) 341-35I.

[52] Williams A.G., Coleman G.S., The Rumen Protozoa, Springer Verlag, New York, 1992

[53] Wolstrup J., Jensen K., Adenosine triphosphate and deoxyribonucleic acid in the alimentary tract of cattle fed different nitrogen sources, J. Appl. Bacteriol. 45 (1978) 49-56.

[54] Yang W.Z., Étude cinétique de la colonisation microbienne des aliments dans le rumen du mouton. Conséquences sur la compartimentation de la biomasse et sur sa dynamique de sortie du rumen dans le cas de différents types de rations, thèse, université de Clermont-Ferrand-II, 1992. 